\title{
SISTEM PAKAR DIAGNOSA PENYAKIT IKAN GURAME DENGAN MENGGUNAKAN FIS MAMDANI
}

\author{
Maria Yunita Nesi ${ }^{1}$, Yampi R Kaesmetan ${ }^{2}$, Meliana O. $\mathrm{Meo}^{3}$ \\ STIKOM Uyelindo, Jl. Perintis Kemerdekaan No.1 - Kayu Putih, Kupang-NTT \\ E-mail:mariayunita.nesi@gmail.com,kaesmetanyampi@gmail.com
}

\begin{abstract}
Abstrack
The carp (Osphronemus Goramy) including fish that was seeded in cultivation. In addition to the price of carp that are relatively more expensive than other fish and it has been easy to carp also has a higher value compared to other freshwater fish. But in the cultivation of carp diseases is one of the serious problems encountered by the fish farmers because it could potentially cause harm. Diseases that attack the carp both are still in the larval or adult forms of which are caused by parasitic infections in the form of fungi, protozoa, worms as well as bacterial infection of Aeromonas hydrophylla, Flexybacter colomnaris, and Mycobacterium sp. The multiplicity of types of disease that can attack the carp and the difficult process of detection because of the similarity of the symptoms caused fish farmers making it difficult to determine the methods of prevention and control of the right to address the disease. Detection of disease of carp is seen on the surface of the body of the fish. Therefore, it takes expert system to detect disease carp by involving technology. One of the methods used in the expert system of fuzzy inference system Mamdani. Fuzzy inference system Mamdani reasoning used in this study because of the handling of the value and accuisition of knowledge representation experts can directly representation in the form of rules, which can be understood when placed on the machine inference. The result of this reasoning is to detect diseases of the carp while delivering the right solution to tackle the disease of carp.
\end{abstract}

Keywords: carp, diseases of the body surface of the fish, expert system, fuzzy logic, Fuzzy Inference System Mamdani.

\section{PENDAHULUAN}

Produksi perikanan budidaya di Indonesia tahun 2014 mencapai 14,3 juta ton atau mengalami kenaikan sebesar $7,96 \%$ dibandingkan tahun 2013 yakni sebesar 13,3 juta ton (Kementrian Kelautan dan Perikanan, 2015).

Berdasarkan analisa data Kementrian Kelautan dan Perikanan tahun 2014, Provinsi Nusa Tenggara Timur menempati urutan kedua produksi ikan budidaya terbesar di Indonesia mencapai 1,97 juta ton. Ikan gurame (Osphronemus Goramy) termasuk ikan yang diunggulkan dalam budidaya (Affandi et al., 2004). Selain harga ikan gurame yang relatif lebih mahal dari ikan lainnya dan memiliki nilai jual yang lebih tinggi dibandingkan dengan ikan air tawar lainnya, Namun dalam budidaya ikan gurame, penyakit merupakan salah satu masalah serius yang dihadapi oleh para pembudidaya ikan karena berpotensi menimbulkan kerugian. Penyakit yang menyerang ikan gurame disebabkan oleh infeksi parasit berupa jamur, protozoa, cacing serta infeksi bacterial dari jenis Aeromonas hydrophylla, Flexybacter colomnaris, dan Mycobacterium $s p$. tiap jenis penyakit memiliki metode pencegahan dan pengendalian yang berbeda. Banyaknya jenis penyakit yang dapat menyerang ikan gurame serta sulitnya proses deteksi karena adanya kemiripan gejala yang ditimbulkan membuat para petani ikan sulit menentukan metode pencegahan dan pengendalian yang tepat untuk mengatasi penyakit tersebut. Masalah lainnya yaitu kurangnya pengetahuan petani ikan tentang penyakit dan solusi pencegahan penyakit ikan gurame membuat proses deteksi hanya berdasarkan pengalaman petani ikan. 
Pendeteksian penyakit ikan gurame dilihat dari ciri pada permukaan tubuh ikan.

Adanya sistem pakar dapat mempermudah kerja atau bahkan mengganti tenaga ahli, menggabungkan ilmu dan pengalaman dari beberapa tenaga ahli, dan menyediakan keahlian yang diperlukan suatu proyek yang tidak memiliki tenaga ahli (Marimin 2009). Salah satu metode sistem pakar yang digunakan adalah dengan menggunakan fuzzy inference system dengan metode Mamdani. Penalaran fuzzy digunakan pada penelitian ini karena penanganan nilai dan representasi pengetahuan yang diakuisasi dari pakar dapat langsung direpresentasi dalam bentuk aturan atau rule, yang bisa dipahami ketika dimasukan pada mesin inferensi. Mulyawanto (2011) melakukan penelitian dengan judul sistem pakar fuzzy untuk diagnosa penyakit pada tanaman cabai merah. Penelitian ini dilakukan berdasarkan atas kebutuhan akan adanya alat bantu bagi petani dalam menentukan atau mengidentifikasi jenis penyakit pada tanaman jagung secara dini.

Berdasarkan konsep Fuzzy Mamdani dan adanya masalah dalam menentukan penyakit yang diderita oleh ikan gurame maka dibutuhkan website untuk mendiagnosa penyakit ikan gurame dengan menerapkan metode Fuzzy Mamdani. Website tersebut dapat mempermudah pembudidaya maupun masyarakat dalam mendiagnosa penyakit pada ikan gurame berdasarkan gejala-gejala yang dialami ikan. Untuk permasalahan ini maka ditarik sebuah solusi yaitu dengan mengimplementasikan Sistem Pakar Diagnosa Penyakit Ikan Gurame Menggunakan Metode Fuzzy Mamdani.

\section{METODELOGI PENELITIAN}

Metodelogi yang digunakan penulis dalam melakukan penelitian tentang penerapan sistem pakar diagnosa penyakit ikan gurame menggunakan fuzzy inference system mamdani terlihat pada gambar 1 berikut:

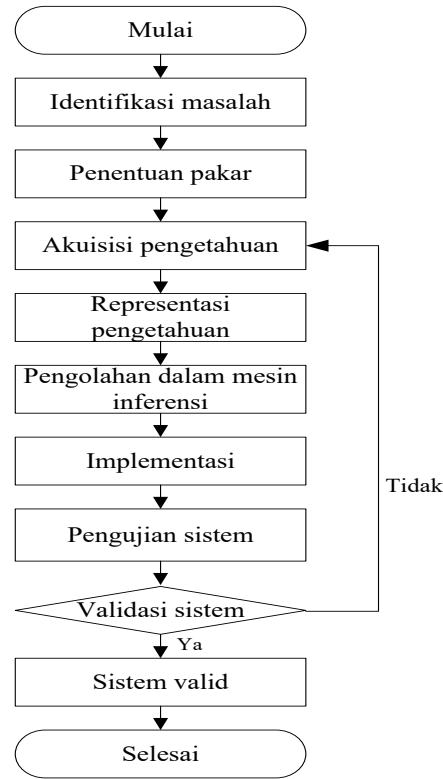

Gambar 1. Prosedur Analisis Data

\subsection{Identifikasi masalah}

Langkah awal untuk mengetahui masalah dari sebuah objek untuk diteliti. Masalah yang diteliti yaitu bagaimana menganalisis dan menentukan faktor penyabab penyakit pada ikan gurame.

\subsection{Penentuan pakar}

Penentuan pakar diambil dari pihak pengelolah program untuk mendapatkan data dan informasi.

\subsection{Akusisi pengetahuan}

Pada penelitian ini dilakukan wawancara dan observasi dilapangan yang dijadikan sebagai bukti hingga memprosesnya kedalam rule. Dari hasil penelitian mendapatkan variabel-variabel yang bisa dijadikan sebagai model untuk mendiagnosa penyakit ikan gurame.

Tabel 1. Penyakit

\begin{tabular}{cl}
\hline $\begin{array}{c}\text { Kode } \\
\text { Penyakit }\end{array}$ & \multicolumn{1}{c}{ Nama Penyakit } \\
\hline P01 & Saprolegniasis \\
P02 & Ichtyiothiriasis, bintik putih atau Ich \\
P03 & Trichodiniasis \\
P04 & Henneguyasis \\
P05 & Septicemia hemorrhagika (bercak merah) \\
P06 & Columnaris \\
P07 & Myxosporidia \\
\hline
\end{tabular}


Tabel 2. Gejala

\begin{tabular}{|c|c|}
\hline $\begin{array}{l}\text { Kode } \\
\text { Gejala }\end{array}$ & Nama Gejala \\
\hline G01 & Muncul selaput berwarna putih \\
\hline G02 & $\begin{array}{l}\text { Muncul bintik putih atau abu-abu pada } \\
\text { bawah lapisan lender }\end{array}$ \\
\hline G03 & $\begin{array}{l}\text { Sirip koyak, geripis dan kerusakan pada } \\
\text { kulit }\end{array}$ \\
\hline G04 & Produksi lender yang berlebihan \\
\hline G05 & Ikan terlihat lesu \\
\hline G06 & Adanya sista putih berdiameter $0,1-3 \mathrm{~mm}$ \\
\hline G07 & $\begin{array}{l}\text { Tubuh ikan berwarna lebih gelap disertai } \\
\text { pendarahan yang tidak normal pada } \\
\text { permukaan tubuh dan sirip }\end{array}$ \\
\hline G08 & $\begin{array}{l}\text { Rongga perut yang membesar akibat } \\
\text { penumpukan cairan }\end{array}$ \\
\hline G09 & $\begin{array}{l}\text { Insang terkelupas, memudar, } \\
\text { membengkak dan tutup insang menganga }\end{array}$ \\
\hline G10 & $\begin{array}{l}\text { Bercak merah terdapat pada pangkal ekor } \\
\text { atau daerah sekitar anus }\end{array}$ \\
\hline G11 & $\begin{array}{l}\text { Mata ikan akan menonjol seperti hendak } \\
\text { jatuh }\end{array}$ \\
\hline G12 & $\begin{array}{l}\text { Benjolan kecil dan bagaian perut } \\
\text { membengkak }\end{array}$ \\
\hline G13 & $\begin{array}{l}\text { Ikan mengosok-gosok badan ke dinding } \\
\text { kolam }\end{array}$ \\
\hline G14 & Berenang tidak normal \\
\hline
\end{tabular}

2.4. Representasi dengan menggunakan kurva segitiga.

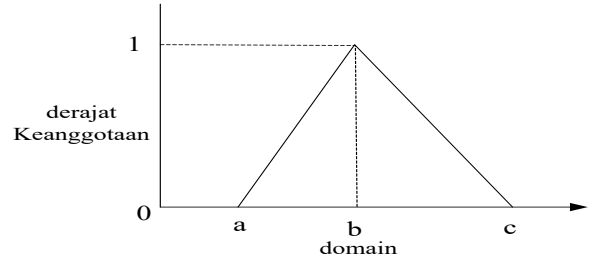

Fungsi keanggotaan:

$$
\mu[\chi]= \begin{cases}0 ; & x \leq \alpha \text { atau } x \geq c \\ (x-\alpha) /(b-\alpha) ; & \alpha \leq x \leq b \\ (b-x) /(c-b & b \leq x \leq c\end{cases}
$$

2.5. Pengolahan dalam mesin inferensi

Sistem inferensi fuzzy yang digunakan dalam perancangan sistem untuk mendiagnosa penyakit ikan gurame adalah fuzzy inference system Mamdani, yang terdiri dari beberapa tahapan yaitu pembentukan himpunan fuzzy, aplikasi fungsi fuzzy (aturan), komposisi aturan dan penegasan (defuzzy).

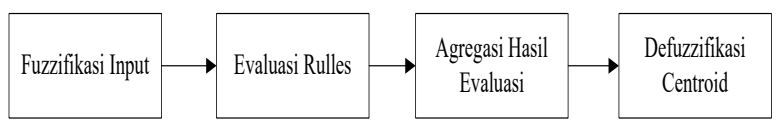

Gambar 2. Proses inferensi dengan metode Mamdani

\subsection{Implementasi}

Pada tahap ini akan dilakukan pengkonversian bahasa manusia ke dalam bahasa pemograman berdasarkan desain yang dibentuk.

\subsection{Pengujian system}

Pengujian dilakukan dengan menggunakan aplikasi yang telah dibuat, dimana data akan diuji penilaiannya dalam pengukuran untuk mencapai tujuan dari data tersebut. Pengujian dilakukan uji coba kepada pakar dan pengguna. Dalam pengujian akan menghitung tingkat akurasi kesalahan dengan persamaan sebagai berikut:

Galat presentasi (per

$$
\begin{gathered}
\text { MAPE }=\frac{1}{n} \sum_{i-1}^{n}\left|P E_{i}\right| \\
\text { centage error): } P E_{t}=\left(\frac{x_{t}-F_{t}}{X_{t}}\right) \times 100 \%
\end{gathered}
$$

\subsection{Rancangan flowchart apikasi}

Flowchart sistem aplikasi sistem pakar diagnosa penyakit ikan gurame dengan menggunakan fuzzy inference system mamdani menggambarkan alur program dari admin dan flowchart untuk mengolah data pakar gejala dan penyakit ikan gurame. Hal ini merupakan fasilitas utama dari sistem yang dibangun.

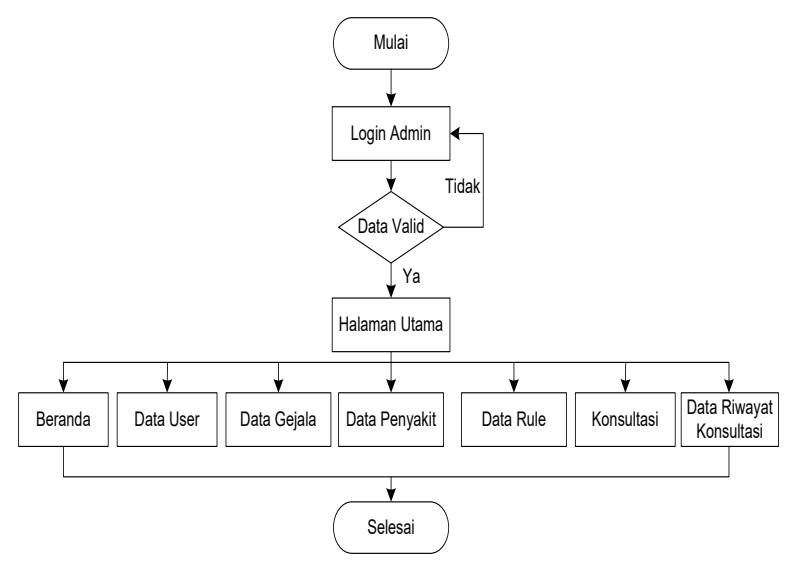

Gambar 3. Flowchart Sistem untuk admin 


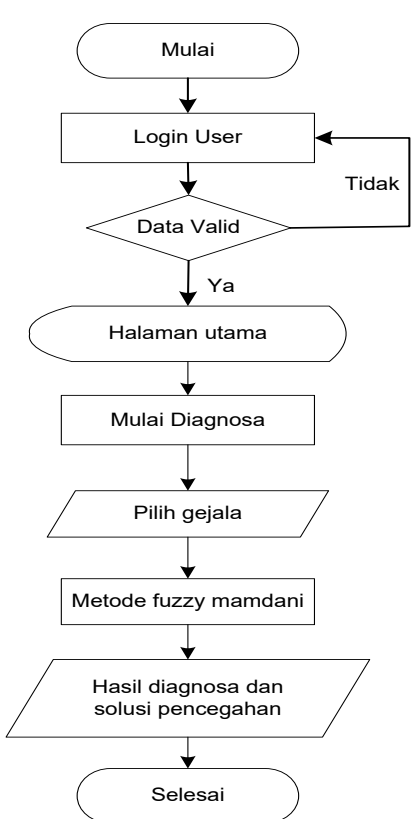

Gambar 4. Flowchart Sistem untuk user

\section{HASIL DAN PEMBAHASAN}

Dari hasil penelitian mendapatkan variabel-variabel yang bisa dijadikan sebagai model untuk mendiagnosa penyakit ikan gurame.

Tabel 3. Himpunan fuzzy

\begin{tabular}{|c|c|c|c|}
\hline Variabel & Himpunan & Rentang & Domain \\
\hline \multirow{3}{*}{ G01 } & Rendah & {$[0-5]$} & {$\left[\begin{array}{lll}0 & 3 & 5\end{array}\right]$} \\
\hline & Sedang & {$[4-8]$} & {$\left[\begin{array}{lll}4 & 6 & 8\end{array}\right]$} \\
\hline & Tinggi & {$[7-10]$} & {$\left[\begin{array}{lll}7 & 9 & 11\end{array}\right]$} \\
\hline \multirow{3}{*}{ G02 } & Rendah & {$[14-18]$} & {$\left[\begin{array}{llll}14 & 16 & 18\end{array}\right]$} \\
\hline & Sedang & {$[17-21]$} & {$\left[\begin{array}{lll}17 & 19 & 21\end{array}\right]$} \\
\hline & Tinggi & {$[20-28]$} & {$\left[\begin{array}{llll}20 & 24 & 28\end{array}\right]$} \\
\hline \multirow{3}{*}{ G03 } & Rendah & {$[20-28]$} & {$\left[\begin{array}{llll}20 & 25 & 28\end{array}\right]$} \\
\hline & Sedang & {$[27-35]$} & {$\left[\begin{array}{llll}27 & 30 & 35\end{array}\right]$} \\
\hline & Tinggi & {$[34-40]$} & {$\left[\begin{array}{llll}3 & 4 & 38 & 40\end{array}\right]$} \\
\hline \multirow{3}{*}{ G04 } & Rendah & {$[6-9]$} & {$\left[\begin{array}{lll}6 & 7 & 9\end{array}\right]$} \\
\hline & Sedang & {$[8-13]$} & {$\left[\begin{array}{llll}8 & 10 & 13\end{array}\right]$} \\
\hline & Tinggi & {$[11-16]$} & {$\left[\begin{array}{llll}1 & 1 & 14 & 16\end{array}\right]$} \\
\hline \multirow{3}{*}{ G05 } & Rendah & {$[11-15]$} & {$\left[\begin{array}{lll}11 & 13 & 15\end{array}\right]$} \\
\hline & Sedang & {$[14-18]$} & {$\left[\begin{array}{llll}14 & 16 & 18\end{array}\right]$} \\
\hline & Tinggi & {$[17-22]$} & {$\left[\begin{array}{llll}1 & 17 & 20 & 22\end{array}\right]$} \\
\hline \multirow{3}{*}{ G06 } & Rendah & {$[5-9]$} & [ [ $\left.\begin{array}{lll}5 & 7 & 9\end{array}\right]$ \\
\hline & Sedang & {$[8-12]$} & {$\left[\begin{array}{llll}8 & 10 & 12\end{array}\right]$} \\
\hline & Tinggi & {$[11-15]$} & 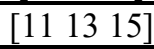 \\
\hline \multirow{3}{*}{ G07 } & Rendah & {$[3-7]$} & {$\left[\begin{array}{lll}3 & 5 & 7\end{array}\right]$} \\
\hline & Sedang & {$[6-10]$} & {$\left[\begin{array}{lll}6 & 8 & 10\end{array}\right]$} \\
\hline & Tinggi & {$[9-13]$} & {$\left[\begin{array}{llll}9 & 1 & 1 & 13\end{array}\right]$} \\
\hline \multirow{3}{*}{ G08 } & Rendah & {$[16-20]$} & {$\left[\begin{array}{llll}16 & 18 & 20\end{array}\right]$} \\
\hline & Sedang & [19 - 23] & {$\left[\begin{array}{lll}19 & 21 & 23\end{array}\right]$} \\
\hline & Tinggi & {$[22-26]$} & {$\left[\begin{array}{llll}22 & 24 & 26\end{array}\right]$} \\
\hline G09 & Rendah & {$[1-5]$} & {$\left[\begin{array}{lll}1 & 3 & 5\end{array}\right]$} \\
\hline
\end{tabular}

\begin{tabular}{|c|c|c|c|}
\hline & Sedang & {$[4-10]$} & {$\left[\begin{array}{lll}4 & 8 & 10\end{array}\right]$} \\
\hline & Tinggi & {$[9-13]$} & {$\left[\begin{array}{llll}9 & 1 & 1 & 13\end{array}\right]$} \\
\hline \multirow{3}{*}{ G10 } & Rendah & {$[25-29]$} & {$\left[\begin{array}{lll}25 & 27 & 29\end{array}\right]$} \\
\hline & Sedang & {$[28-32]$} & {$\left[\begin{array}{llll}28 & 30 & 32\end{array}\right]$} \\
\hline & Tinggi & {$[31-35]$} & {$\left[\begin{array}{llll}3 & 1 & 33 & 35\end{array}\right]$} \\
\hline \multirow{3}{*}{ G11 } & Rendah & {$[13-17]$} & {$\left[\begin{array}{llll}13 & 15 & 17\end{array}\right]$} \\
\hline & Sedang & {$[16-24]$} & {$\left[\begin{array}{lll}16 & 20 & 24\end{array}\right]$} \\
\hline & Tinggi & {$[21-28]$} & {$\left[\begin{array}{llll}21 & 26 & 28\end{array}\right]$} \\
\hline \multirow{3}{*}{ G12 } & Rendah & {$[5-12]$} & {$\left[\begin{array}{lll}5 & 8 & 12\end{array}\right]$} \\
\hline & Sedang & {$[11-25]$} & {$\left[\begin{array}{llll}1 & 1 & 20 & 25\end{array}\right]$} \\
\hline & Tinggi & {$[24-38]$} & {$\left[\begin{array}{llll}2 & 4 & 32 & 38\end{array}\right]$} \\
\hline \multirow{3}{*}{ G13 } & Rendah & {$[3-7]$} & {$\left[\begin{array}{lll}3 & 5 & 7\end{array}\right]$} \\
\hline & Sedang & {$[6-12]$} & {$\left[\begin{array}{lll}6 & 8 & 12\end{array}\right]$} \\
\hline & Tinggi & {$[11-15]$} & $\left.\begin{array}{llll}11 & 13 & 15\end{array}\right]$ \\
\hline \multirow{3}{*}{ G14 } & Rendah & {$[10-14]$} & {$\left[\begin{array}{llll}10 & 12 & 14\end{array}\right]$} \\
\hline & Sedang & {$[13-18]$} & {$\left[\begin{array}{llll}13 & 16 & 18\end{array}\right]$} \\
\hline & Tinggi & {$[17-21]$} & {$\left[\begin{array}{llll}17 & 19 & 21\end{array}\right]$} \\
\hline
\end{tabular}

Dalam penerapan fuzzy inference system Mamdani pada perangkat lunak diagnose penyakit ikan gurame yang penulis rancang ini terdapat 14 variabel input yaitu: G01 sampai G14. Misalnya diambil nilai $\mathrm{G} 01=10 ; \mathrm{G} 02$ $=20,5 ; \mathrm{G} 03=34,2 ; \mathrm{G} 04=12 ; \mathrm{G} 05=21 ; \mathrm{G} 06=$ 14,$1 ; \mathrm{G} 07=9,2 ; \mathrm{G} 08=22,5 ; \mathrm{G} 09=11,5 ; \mathrm{G} 10$ $=34,4 ; \mathrm{G} 11=22 ; \mathrm{G} 12=24,5 ; \mathrm{G} 13=10,8$ dan $\mathrm{G} 14=17,3$.

\subsection{Fuzzifikasi input}

a) Nilai G01(10)

$\mu \mathrm{G} 01$ Rendah $[\propto]=0$

$\mu \mathrm{G} 01$ Sedang $[\propto]=0$

$\mu \mathrm{G} 01$ Tinggi $[\propto]=\frac{10-7}{11-7}=0,75$

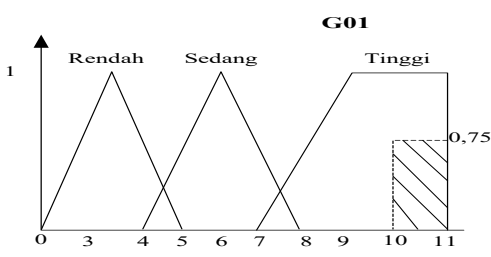

Gambar 5. Fungsi keanggotaan G01

b) Nilai G02(20,5)

$\mu \mathrm{G} 02 \operatorname{Rendah}[\propto]=0$

$\mu \mathrm{G} 02 \operatorname{Sedang}[\propto]=\frac{21-20,5}{19-17}=0,25$

$\mu \mathrm{G} 02$ Tinggi $[\propto]=\frac{20,5-20}{28-20}=0,0625$

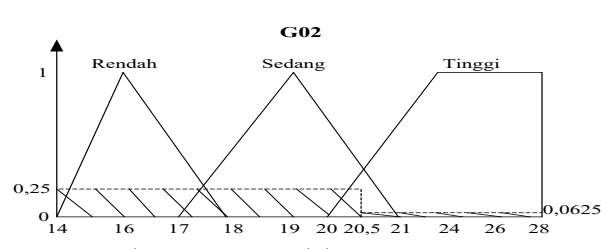

Gambar 6. Fungsi keanggotaan G02 
c) Nilai G03(34,2)

$\mu \mathrm{G} 03$ Rendah $[\propto]=0$

$\mu \mathrm{G03Sedang}[\propto]=\frac{35-34,2}{30-27}=0,27$

$\mu \mathrm{G03Tinggi}[\propto]=\frac{34,2-34}{40-34}=0,033$

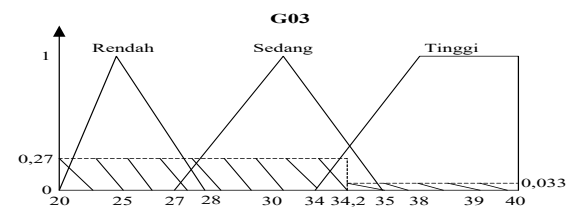

Gambar 7. Fungsi keanggotaan G03

d) Nilai G04(12)

$\mu \mathrm{G04Rendah}[\propto]=0$

$\mu \mathrm{G} 04$ Sedang $[\propto]=\frac{13-12}{10-8}=0,5$

$\mu \mathrm{G} 04$ Tinggi $[\propto]=\frac{12-11}{16-11}=0$,

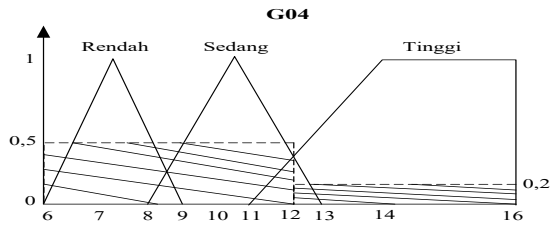

Gambar 8. Fungsi keanggotaan G04

e) Nilai G05(21)

$\mu \mathrm{G05Rendah}[\propto]=0$

$\mu \mathrm{G} 05$ Sedang $[\propto]=0$

$\mu \mathrm{G05Tinggi}[\propto]=\frac{21-17}{22-17}=0,8$

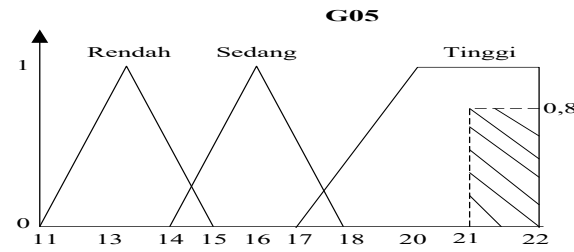

Gambar 9. Fungsi keanggotaan G05

f) Nilai G06(14,1)

$\mu$ G06Rendah $[\propto]=0$

$\mu \mathrm{G} 06$ Sedang $[\propto]=0$

$\mu \mathrm{G06Tinggi}[\propto]=\frac{14,1-11}{15-11}=0,775$

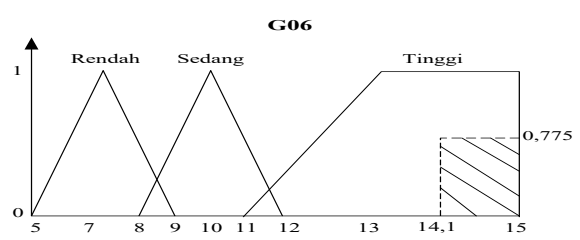

Gambar 10. Fungsi keanggotaan G06

g) Nilai G07(9,2)

$\mu$ G07Rendah $[\propto]=0$

$\mu \mathrm{G} 07$ Sedang $[\propto]=\frac{10-9,2}{8-6}=0,4$ $\mu \mathrm{G} 07$ Tinggi $[\propto]=\frac{9,2-9}{13-9}=0,05$

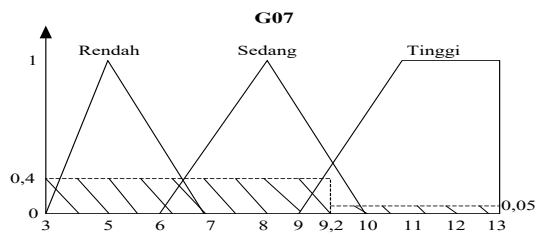

Gambar 11. Fungsi keanggotaan G07

h) Nilai G08(22,5)

$\mu \mathrm{G} 08$ Rendah $[\propto]=0$

$\mu \mathrm{G} 08$ Sedang $[\propto]=\frac{23-22,5}{21-19}=0,25$

$\mu \mathrm{G08Tinggi}[\propto]=\frac{22,5-22}{26-22}=0,125$

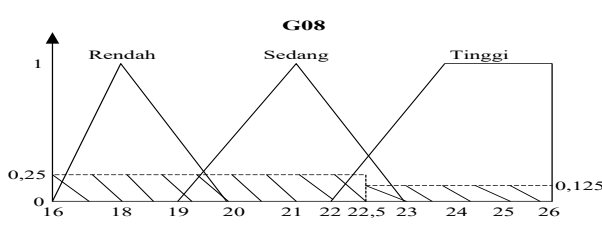

Gambar 12. Fungsi keanggotaan G08

i) Nilai G09(11,5)

$\mu \mathrm{G} 09$ Rendah $[\propto]=0$

$\mu \mathrm{G} 09$ Sedang $[\propto]=0$

$\mu \mathrm{G} 09$ Tinggi $[\propto]=\frac{11,5-9}{13-9}=0,63$

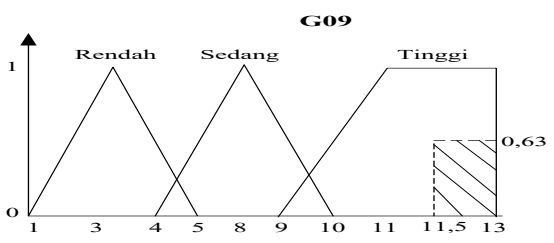

Gambar 13. Fungsi keanggotaan G09

j)Nilai G10 $(34,4)$

$\mu \mathrm{G} 10$ Rendah $[\propto]=0$

$\mu \mathrm{G} 10$ Sedang $[\propto]=0$

$\mu \mathrm{G} 10$ Tinggi $[\propto]=\frac{34,4-31}{35-31}=0,6$

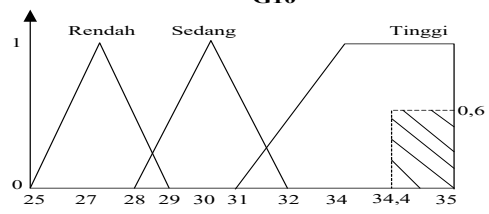

Gambar 14. Fungsi keanggotaan G10

k) Nilai G11(22)

$\mu \mathrm{G} 11$ Rendah $[\propto]=0$

$\mu \mathrm{G} 11$ Sedang $[\propto]=\frac{24-22}{20-16}=0,5$

$\mu \mathrm{G} 11$ Tinggi $[\propto]=\frac{22-21}{28-21}=0,143$ 


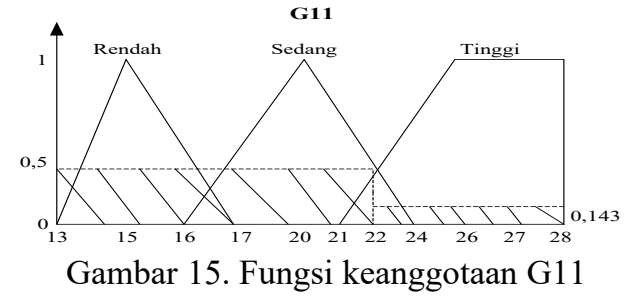

1)Nilai $G 12(24,5)$

$\mu \mathrm{G} 12$ Rendah $[\propto]=0$

$\mu \mathrm{G} 12$ Sedang $[\propto]=\frac{25-24,5}{20-11}=0,1$

$\mu \mathrm{G} 12$ Tinggi $[\propto]=\frac{24,5-24}{38-24}=0,06$

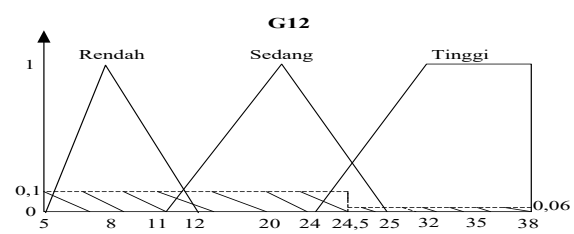

Gambar 16. Fungsi keanggotaan G12

m) Nilai G13 $(10,8)$

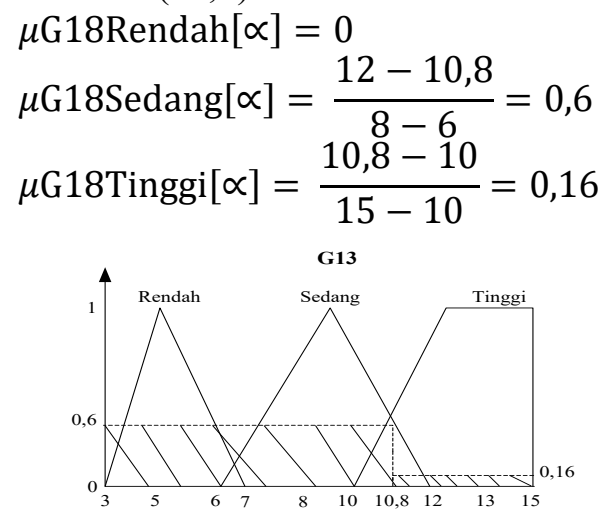

Gambar 17. Fungsi keanggotaan G13

n) Nilai G14(17,3)

$$
\begin{aligned}
& \mu \mathrm{G} 14 \operatorname{Rendah}[\propto]=0 \\
& \mu \mathrm{G} 14 \text { Sedang }[\propto]=\frac{18-17,3}{16-13}=0,233 \\
& \mu \mathrm{G} 14 \operatorname{Tinggi}[\propto]=\frac{17,3-17}{21-17}=0,075
\end{aligned}
$$

\subsection{Aplikasi fungsi implikasi}

Aturan yang digunakan dalam diagnosa penyakit ikan gurame yang diteliti terdapat 25 rule, dengan masing-masing rule menggunakan metode Fuzzy Mamdani. R1. If G03 rendah (0) AND G04 rendah (0)
AND G05 rendah (0) AND G14 rendah (0)

\section{THEN P02 Trichodiniasis}

If G03 rendah (0) AND G04 rendah (0)

R2. AND G05 rendah (0) AND G14 sedang $(0,233)$ THEN P02 Trichodiniasis

If G03 rendah (0) AND G04 rendah (0)

R3. AND G05 rendah (0) AND G14 tinggi $(0,075)$ THEN P02 Trichodiniasis

If G03 rendah (0) AND G04 rendah (0)

R4 AND G05 sedang (0) AND G14 rendah (0) THEN P02 Trichodiniasis

If G03 rendah (0) AND G04 rendah (0)

R5 AND G05 tinggi $(0,8)$ AND G14 rendah $(0)$ THEN P02 Trichodiniasis

If G03 rendah (0) AND G04 sedang $(0,5)$

R6 AND G05 rendah (0) AND G14 rendah (0) THEN P02 Trichodiniasis

If G03 rendah (0) AND G04 tinggi $(0,2)$

R7 AND G05 rendah (0) AND G14 rendah (0) THEN P02 Trichodiniasis

If G03 sedang $(0,27)$ AND G04 rendah (0)

R8 AND G05 rendah (0) AND G14 rendah (0) THEN P02 Trichodiniasis

If G03 tinggi $(0,033)$ AND G04 rendah (0)

R9 AND G05 rendah (0) AND G14 rendah (0)

THEN P02 Trichodiniasis

If G03 tinggi $(0,033)$ AND G04 tinggi

R10 (0,2) AND G05 tinggi (0,8) AND G14 tinggi $(0,075)$ THEN P02 Trichodiniasis

$\alpha-$ predikat10 $=\mu_{\mathrm{G} 03}$ TINGGI $\cap$

$\mu_{\text {G04 }}$ TINGGI $\cap \mu_{\text {G05 }}$ TINGGI $\cap$

$\mu_{\text {G14 }}$ TINGGI

$=\min (0,033 ; 0,2 ; 0,8 ; 0,075)$

$=\mathbf{0 , 0 3 3}$

If G03 tinggi $(0,033)$ AND G04 rendah 0()

R11 AND G05 sedang (0) AND G14 rendah (0) THEN P02 Trichodiniasis

If G03 tinggi $(0,033)$ AND G04 sedang

R12 $(0,5)$ AND G05 rendah (0) AND G14 rendah

(0) THEN P02 Trichodiniasis

If G03 tinggi $(0,033)$ AND G04 rendah (0)

R13 AND G05 sedang (0) AND G14 sedang $(0,233)$ THEN P02 Trichodiniasis

If G03 sedang $(0,27)$ AND G04 sedang

R14 (0,5) AND G05 sedang (0) AND G14 rendah (0) THEN P02 Trichodiniasis

If G03 sedang $(0,27)$ AND G04 sedang

R15 (0,5) AND G05 sedang (0) AND G14 sedang $(0,233)$ THEN P02 Trichodiniasis

If G03 sedang $(0,27)$ AND G04 tinggi

R16 (0,2) AND G05 tinggi $(0,8)$ AND G14 tinggi $(0,075)$ THEN P02 Trichodiniasis

$\alpha-$ predikat16 $=\mu_{\mathrm{G} 03}$ SEDANG $\cap$

$\mu_{\text {G04 }}$ TINGGI $\cap \mu_{\text {G05 }}$ TINGGI $\cap$

$\mu_{\text {G14 }}$ TINGGI

$=\min (0,27 ; 0,2 ; 0,8 ; 0,075)$

$=\mathbf{0 , 0 7 5}$

If G03 rendah (0) AND G04 sedang $(0,5)$

R17 AND G05 sedang (0) AND G14 sedang $(0,233)$ THEN P02 Trichodiniasis 
If G03 sedang $(0,27)$ AND G04 sedang

R18 (0,5) AND G05 sedang (0) AND G14 tinggi $(0,075)$ THEN P02 Trichodiniasis

If G03 tinggi $(0,033)$ AND G04 tinggi $(0,2)$

R19 AND G05 sedang (0) AND G14 tinggi $(0,075)$ THEN P02 Trichodiniasis

If G03 sedang $(0,27)$ AND G04 rendah (0)

R20 AND G05 sedang (0) AND G14 sedang $(0,233)$ THEN P02 Trichodiniasis

If G03 sedang $(0,27)$ AND G04 tinggi $(0,2)$

R21 AND G05 sedang (0) AND G14 rendah (0) THEN P02 Trichodiniasis

If G03 sedang $(0,27)$ AND G04 tinggi $(0,2)$

R22 AND G05 sedang (0) AND G14 sedang $(0,233)$ THEN P02 Trichodiniasis

If G03 tinggi (0,033) AND G04 tinggi

R23 (0,2) AND G05 tinggi (0,8) AND G14 sedang (0,233) THEN P02 Trichodiniasis

$\alpha-$ predikat23 $=\mu_{\text {G03 }}$ TINGGI $\cap$

$\mu_{\mathrm{G} 04}$ TINGGI $\cap \mu_{\mathrm{G} 05}$ TINGGI $\cap$

$\mu_{\text {G14 SEDANG }}$

$=\min (0,033 ; 0,2 ; 0,8 ; 0,233)$

$=\mathbf{0 , 0 3 3}$

If G03 sedang $(0,27)$ AND G04 sedang $(0,5)$

R24 AND G05 rendah (0) AND G14 rendah (0) THEN P02 Trichodiniasis

If G03 rendah $(0,033)$ AND G04 sedang $(0,5)$

R25 AND G05 sedang (0) AND G14 rendah (0)

THEN P02 Trichodiniasis

\subsection{Komposisi aturan}

Komposisi aturan menggunakan fungsi max. Karena dari 25 aturan yang ada 3 aturan yang memiliki $\boldsymbol{\alpha}$ - predikat yang $>0$ maka komposisi aturannya menjadi: $\operatorname{Max}(\boldsymbol{\alpha}-$ predikat10, $\alpha$-predikat16, $\alpha$-predikat23)

$\operatorname{Max}(0,033 ; 0,075 ; 0,033)$

$$
=0,075
$$

$\left(\mathrm{a}_{1}-0\right) / 100=0,033$

$\left(a_{2}-0\right) / 100=0,075$

3.4. Penegasan / Defuzzifikasi

Penegasan menggunakan metode centroid momen.

$$
\begin{aligned}
& z^{*}=\frac{\sum_{j=1}^{n} z_{j} \mu\left(z_{j}\right)}{\sum_{j=1}^{n} \mu\left(z_{j}\right)} \\
& z^{*}=\frac{3.5547}{22.141}
\end{aligned}
$$$$
z^{*}=0.16055
$$

\subsection{Implementasi}

3.5.1. Tampilan menu login

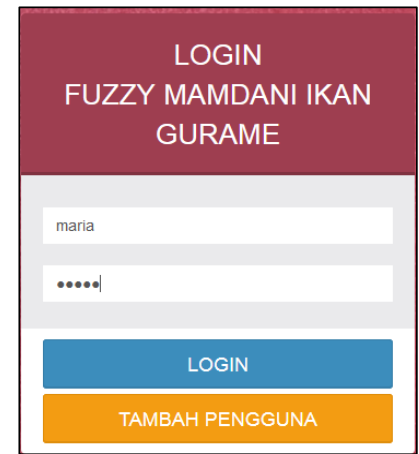

Gambar 19. Tampilan menu login

3.5.2. Tampilan menu beranda

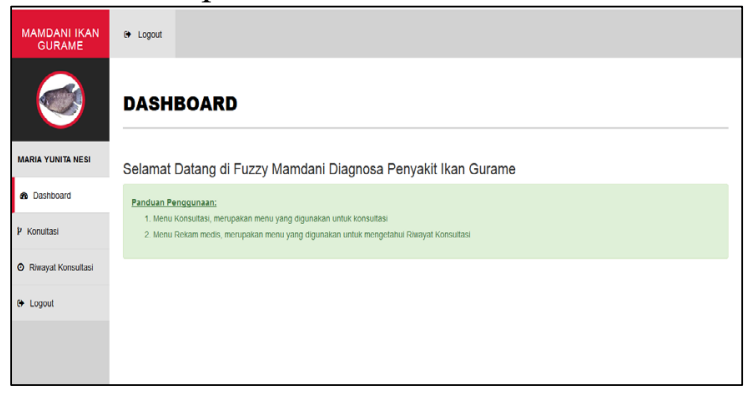

Gambar 20. Tampilan menu beranda

3.5.3. Tampilan menu konsultasi

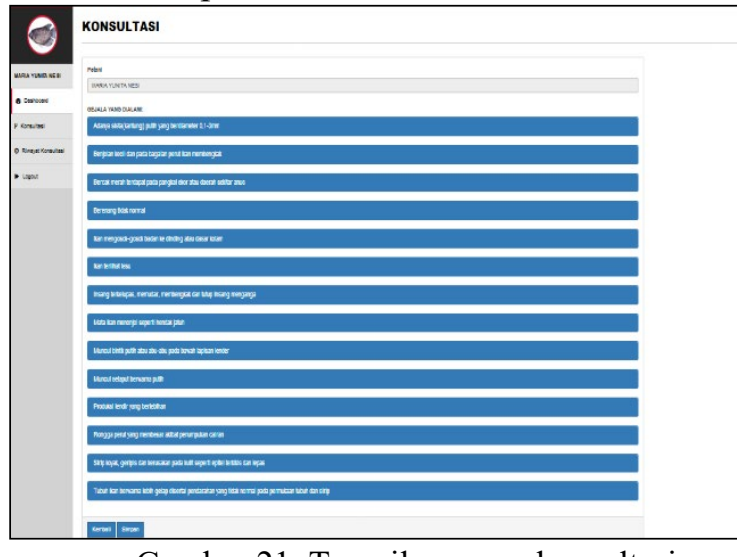

Gambar 21. Tampilan menu konsultasi

3.5.4. Tampilan menu riwayat konsultasi

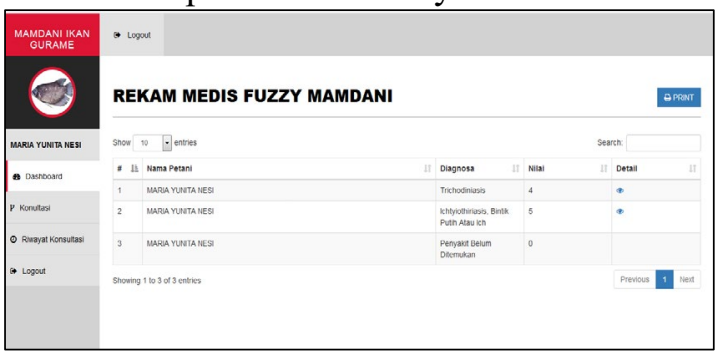

Gambar 22. Tampilan menu riwayat konsultasi

\section{KESIMPULAN}

Simpulan dari hasil penelitian ini adalah sistem pakar dalam mendiagnosa penyakit ikan gurame menghasilkan akurasi 
mencapai $83 \%$ dengan tingkat keerorannya $0,17 \%$. Dari hasil tersebut dapat disimpulkan bahwa aplikasi sistem pakar diagnosa penyakit ikan gurame dengan menggunakan Fuzzy Inference System Mamdani dapat digunakan untuk mengetahui penyakit yang menyerang ikan gurame berdasarkan gejala pada permukaan tubuh dan kesamaan gejala pada tiap penyakit. Fungsi dari aplikasi ini mempermudah petani ikan dalam mendiagnosa penyakit ikan gurame secara cepat dan efisien.

\section{DAFTAR PUSTAKA}

[1] Amali D. 2014. Aplikasi Model Fuzzy dalam Prediksi Produksi Telur Ayam Petelur Di Kabupaten Sleman. [Skripsi]. Yogyakarta [ID]: Universitas Negeri Yogyakarta.

[2] Dewi S, Adhistya E. Hanung A. 2014. Diagnosa Dini Penyakit Gangguan Jiwa Menggunakan Metode Fuzzy Mamdani. Seminar Nasional Teknologi Informasi dan Multimedia 2018 [Internet]. [Diunduh 2014 Februari 8]. Tersedia pada: http://ojs.amikom.ac.id. Yogyakarta [ID]: STMIK Amikom Yogyakarta.

[3] Haryanto T. 2006. Sistem Pakar Diagnosa Penyakit Pada Ayam. [Skripsi]. Bogor [ID]: Institut Pertanian Bogor.

[4] Jogiyanto H. 2005. Analisis dan Desain Sistem Informasi: Pendekatan Terstruktur Teori dan Praktek Aplikasi Bisnis. Jurnal Yogyakarta Andi. Yogyakarta [ID]: Universitas Gadjah Mada.

[5] Kamsyakawuni A, Rachmad G, Eko Adi S. 2012. Aplikasi Sistem Pakar untuk Diagnosa Penyakit Hipertiroid dengan Metode Inferensi Fuzzy Mamdani. Jurnal Sistem Informasi Bisnis [Internet]. [Diunduh Februari 2012]. Tersedia pada: http://ejournal.undip.ac.id/index.php/jsinbis.

[6] Kusumadewi S. 2006. Fuzzy Multi-Attribute Decision Making (Fuzzy MADM). Yogyakarta [ID]: Graha Ilmu Yogyakarta

[7] Mulyanto M. 2011. Sistem Pakar Fuzzy Untuk Diagnosa Penyakit Pada Tanaman Cabai Merah. [Skripsi]. Bogor [ID]: Institut Pertanian Bogor.

[8] Noor J. 2011. Metodologi Penelitian: Skripsi, Tesis, Disertasi dan Karya Ilmiah.
Jakarta [ID]: Kencana Prenada Media Group.

[9] Primartha N, Fathiyah. 2013. Sistem Pakar Fuzzy untuk Diagnosa Kanker Payudara Menggunakan Metode Mamdani. Jurnal Generic Vol. 8 No.1 [Internet]. [Diunduh Maret 2013]. Palembang [ID]: Universitas Sriwijaya.

[10] Saputra A, Wisnu B, Ainil S. 2015. Logika Fuzzy Pada Proses Pelet Pakan Ikan. Prosiding Seminar Nasional Fisika (EJournal) SNF Vol. IV [Internet]. [Diunduh 2015 Oktober]. Tersedia pada: http://journal.unj.ac.id.

[11] Setyabudi D. 2007. Sistem Pakar Diagnosa Penyakit Udang Windu (Penaeus monodo) Menggunakan Logika Fuzzy. [Skripsi]. Bogor [ID]: Institut Pertanian Bogor. 